\title{
Enhancing the quality of teacher-child interactions in Singapore pre-school classrooms
}

\author{
Nirmala Karuppiah ${ }^{1}$
}

\begin{abstract}
This exploratory study was aimed primarily at developing baseline data on the quality of teacher-child interactions in Singapore pre-school classrooms. Data were collected through observations of teacher-child interactions in 80 pre-schools, using the Classroom Assessment Scoring System (CLASS) in the three key domains which are 1) Emotional Support, 2) Classroom Organisation, and 3) Instructional Support (Pianta, La Paro, \& Hamre, 2008). It was found that the overall quality of teacher-child interactions in the Singapore pre-school classrooms was low to moderate, with Instruction Support being the lowest. This finding is similar to that found in studies conducted in many other countries including China and the U.S. (Slot, 2017). Possible reasons and explanations will be presented, and suggestions to improve or enhance the quality of teacher-child interactions will be proposed. This study has implications on pre-school teacher education and professional development as well as government policies and regulations for the Singapore pre-school sector.
\end{abstract}

\author{
Article History \\ Received: 04 January 2021 \\ Accepted: 17 February 2021 \\ Keywords \\ Teacher-child interactions; \\ Instructional support; \\ Teacher education; \\ Professional development; \\ Singapore pre-schools
}

\section{Introduction}

As young children in Singapore are spending a large part of their time in pre-schools, it has become increasingly important to determine the nature and quality of their experiences in pre-schools (childcare centres or kindergartens). While there is no universally accepted definition of quality in pre-school education, there are structural and process indicators that are important components of quality programmes which result in positive child outcomes (Organisation for Economic Co-operation and Development [OECD], 2018; Thomason \& LaParo, 2009).

Structural indicators include programmes and features of the classroom such as class size, teacherchild ratios, and teacher qualifications, training and experience (OECD, 2018; Ramey \& Ramey, 2004). These structural variables are the measurable components of quality and most often found in the licensing requirements set by the authorities to ensure that pre-schools provide the minimum quality of services (Karuppiah, 2015; OECD, 2018). Process indicators, on the other hand, include dynamic aspects of the classroom such as planning of learning activities, teacher-parent relationships and teacher-child interactions (OECD, 2018; Ramey \& Ramey, 2004). While these process variables are not regulated by licensing requirements, they determine the quality of children's experiences within the pre-school environment (Karuppiah, 2015; OECD, 2018).

Researchers have identified teacher-child interactions as a key process indicator which contributes to the quality of children's learning experiences (Bertram et al., 2016; Mashburn et al., 2008). Broadly defined, teacher-child interactions are the exchanges that take place between the child and the teacher on both a formal (instructional) and informal (social) basis (Hamre et al., 2012). The quality of teacher-child interactions are dependent on the professionalism of the teachers and the wisdom of their practice and are also influenced by the teachers' background, beliefs and values (Berthelsen, Brownlee, \& Karuppiah, 2011). 
Enhancing the quality of teacher-child interactions...

In particular, responsive, sensitive, stimulating teacher-child interactions are reliably linked to the level of teacher education and specialized professional development training of teachers (Burchinal, PeisnerFeinberg, Pianta, \& Howes, 2002; OECD, 2018).

However, research indicates that teachers with higher qualifications together with specific training in early childhood education are most likely to provide high quality early childhood programmes (Berthelsen et al., 2011; Karuppiah, 2015). There seems to be greater interactions between teachers and children, and the children show greater social, cognitive and language abilities (Burchinal et al., 2002; Fukkink, Helmerhorst, Deynoot Schaub, \& Sluiter, 2019). Additionally, these teachers were found to be more positive and less punitive, employing a less authoritarian style of interactions with the children (Fukkink et al., 2019).

Professional development and coaching are also found to have a positive impact on teachers' interactions with children. However, it was found that the design, duration, delivery and focus of training is important to ensure the effectiveness of professional development for teachers (Pianta et al., 2014). Additionally, it was also found that for the professional development to be effective, it must provide opportunities for sustained training experiences and self-reflection (Schachter, Gerde, \& Hatton-Bowers, 2019; Zan \& Donegan-Ritter, 2014). Creating a positive organisational climate and setting up professional learning communities have also been found to improve teachers' self-image and well-being as well as teacher-child interactions in the pre-school classrooms (OECD, 2018).

Research also suggests that child factors (e.g., characteristics, temperament, self-regulation, attention \& socio-emotional skills) and home factors (e.g., maternal education, socio-economic status \& stress) also affect children's learning because they influence children's engagement in activities and facilitate (or disrupt) classroom processes (Ladd, Birch, \& Buhs, 1999; Pianta \& Stuhlman, 2004). Although there is no definitive answer regarding the ideal teacher-child ratio, teachers in classrooms with smaller class size and lower teacher-to-child ratios tend to be more sensitive and responsive to the children than teachers who had more children in their care (Hoang, Holopainen, \& Siekkinen, 2018; National Institute of Child Health and Human Development, Early Child Care Research Network [NICHD ECCRN], 2004; OECD, 2018).

Since the pre-schools in Singapore are regulated by the licensing requirements stipulated by the Early Childhood Development Agency (ECDA, 2020), it is somewhat fair to conclude that all or most preschools do meet at least the minimum requirements for the structural indicators (Karuppiah, 2015; Tan, 2017). Although there are many structural and process indicators which affect children's outcomes, this study focuses specifically, on teacher-child interactions. Since teacher-child interaction is identified as a key process indicator which contributes to the quality of children's learning experiences, the key research question for this study is, 'What is the quality of teacher-child interactions in Singapore pre-school classrooms'?

\section{Methodology}

The Singapore Kindergarten Impact Project (SKIP) was the first five-year longitudinal study aimed at tracking children from Kindergarten 1 (K1) to Kindergarten 2 (K2) and then, to Primary One (P1) in Singapore. This exploratory study which was part of SKIP, was aimed primarily at developing baseline data on teacher-child interactions in K (K1 \& K2) classrooms in Singapore.

\section{Participants}

The sample consisted of approximately 120 teachers and $1530 \mathrm{~K}$ children in 80 pre-schools located across Singapore. These pre-schools which belonged to three categories of providers (government, government-funded \& private kindergartens or childcare centres), were recruited using a stratified sampling technique. Hence, these pre-schools (mostly kindergartens with 3- or 4- hour programmes) provided a wide variability in terms of their social and economic status (SES), and racial and cultural backgrounds (Chinese, Malays, Indians \& Others).

Prior to the study, approval for ethics clearance was sought from the Nanyang Technological 
University Internal Review Board (NTU IRB). Once approval was obtained, teachers and children (through their parents) were invited to participate in the study through formal information and consent letters. Written consent was obtained from the teachers and parents of the children who were willing to participate in the study. Child assent forms were also completed by the children to confirm their willingness to participate in the study. The teachers, parents and children were briefed on the purpose of the study, data collection procedures and confidentiality of their responses. They were also informed that participation was voluntary, and that they could withdraw participation at any point of the study.

\section{Data Collection}

\section{Instrument}

The Classroom Assessment Scoring System (CLASS), which is an internationally recognised instrument (OECD, 2018), was used to measure the quality of teacher-child interactions in the Singapore pre-school classrooms. CLASS was developed by Pianta and his colleagues (2008) at the Curry School of Education in Virginia, United States of America.

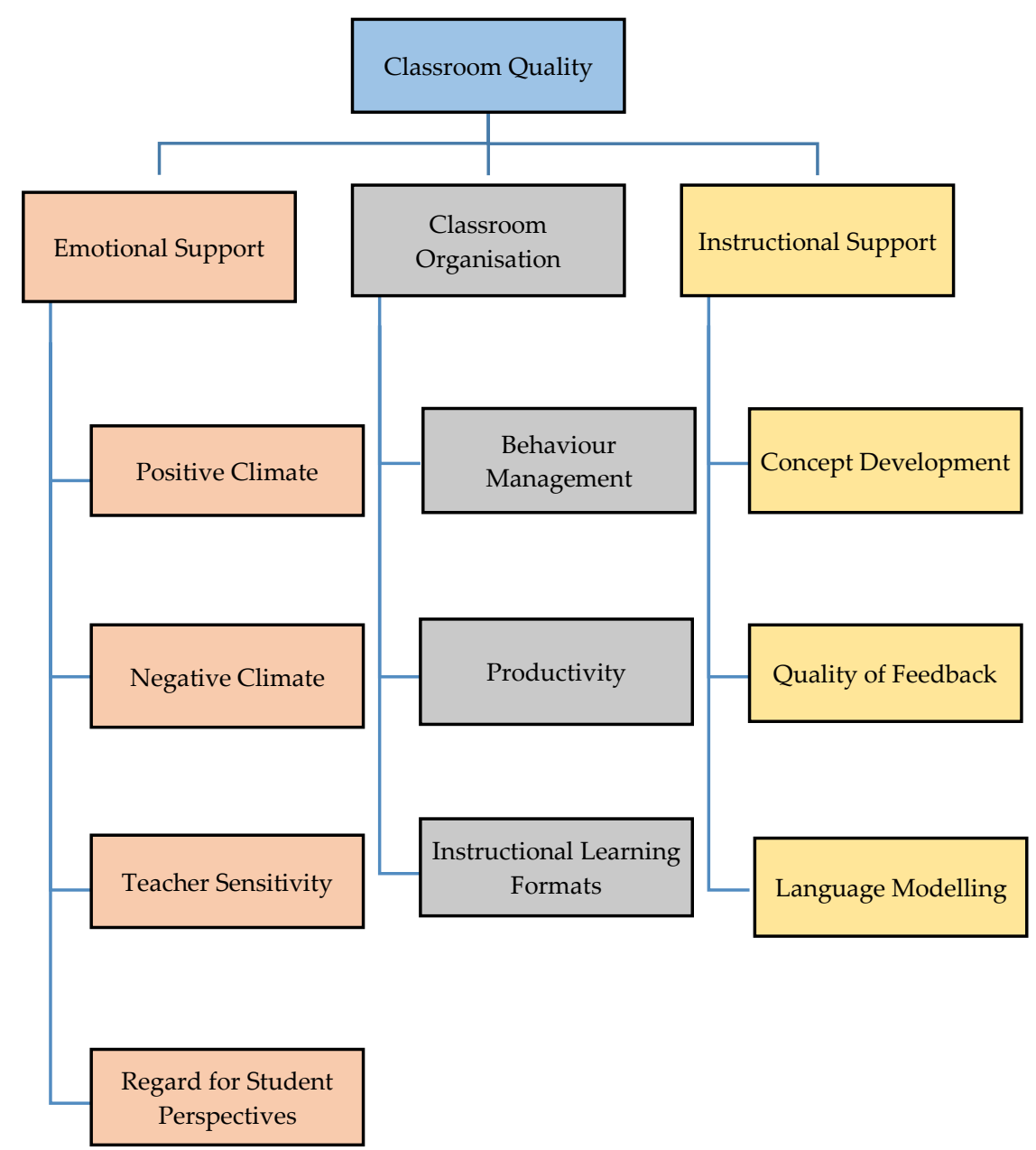

Figure 1. Domains \& Dimensions in CLASS (Pianta et al., 2008)

As depicted in Figure 1, there are ten dimensions in CLASS which are Positive Climate, Negative Climate, Teacher Sensitivity, Regard for Student Perspectives, Behaviour Management, Productivity, Instructional Learning Formats, Concept Development, Quality of Feedback and Language Modelling (Pianta et al., 2008). Each of these dimensions is described in Table 1. 
Enhancing the quality of teacher-child interactions...

Table 1. Observable dimensions in CLASS (Pianta et al., 2008)

\begin{tabular}{|c|c|c|}
\hline Domain & Dimension & Description \\
\hline \multirow{4}{*}{$\begin{array}{l}\text { Emotional } \\
\text { Support }\end{array}$} & Positive Climate & $\begin{array}{l}\text { This is the degree to which the classroom reflects 1) enthusiasm and enjoyment children } \\
\text { display during learning activities, 2) respect displayed during interactions between the } \\
\text { teacher and children, and among children, and 3) positive affect and positive } \\
\text { communication. }\end{array}$ \\
\hline & $\begin{array}{l}\text { Negative } \\
\text { Climate }\end{array}$ & $\begin{array}{l}\text { This is the degree to which the classroom has 1) a negative emotional and social tone, and } \\
\text { 2) negative affect such as anger, harshness, punitive control, sarcasm and severe } \\
\text { negativity such as bullying or physical punishment. }\end{array}$ \\
\hline & $\begin{array}{l}\text { Teacher } \\
\text { Sensitivity }\end{array}$ & $\begin{array}{l}\text { This is the extent to which the teacher 1) provides comfort, reassurance and } \\
\text { encouragement, 2) is aware of children's needs for support, 3) provides individualized } \\
\text { support, 4) is responsive to children's emotions, 5) addresses problems in a timely } \\
\text { manner, and 6) creates a classroom in which children are comfortable seeking out the } \\
\text { teacher and volunteering responses. }\end{array}$ \\
\hline & $\begin{array}{l}\text { Regard for } \\
\text { Student } \\
\text { Perspectives }\end{array}$ & $\begin{array}{l}\text { This is the extent to which the teacher 1) provides classroom activities which are rigidly } \\
\text { structured or regimented, 2) shows flexibility with respect to children's ideas, 3) follows } \\
\text { children's leads, supports autonomy and leadership, and 3) maintains a balance of } \\
\text { teacher talk and child talk in the classroom. }\end{array}$ \\
\hline \multirow{3}{*}{$\begin{array}{l}\text { Classroom } \\
\text { Organisation }\end{array}$} & $\begin{array}{l}\text { Behaviour } \\
\text { Management }\end{array}$ & $\begin{array}{l}\text { This involves the teacher's ability to 1) use effective methods to prevent and redirect } \\
\text { children's misbehaviours, 2) provide clear behaviour expectations, 3) monitor the } \\
\text { classrooms and children's behaviour, and 4) redirect children's behaviour effectively. }\end{array}$ \\
\hline & Productivity & $\begin{array}{l}\text { This involves the teacher's ability to 1) manage instructional time and routines so that } \\
\text { children learn and make progress, 2) provide activities in a way so that children are not } \\
\text { waiting or wandering, 3) have routines that the children understand and can follow in } \\
\text { the classroom, 4) have brief transitions that may incorporate learning opportunities, and } \\
\text { 5) have materials ready for activities to minimize waiting time. }\end{array}$ \\
\hline & $\begin{array}{l}\text { Instructional } \\
\text { Learning } \\
\text { Formats } \\
\end{array}$ & $\begin{array}{l}\text { This involves the teacher's ability to use 1) available activities, method of presentation, } \\
\text { groupings, and range of materials to maximize children's engagement and exploration in } \\
\text { learning, 2) questions to engage children and 3) activities to expand children's learning. }\end{array}$ \\
\hline \multirow{3}{*}{$\begin{array}{l}\text { Instructional } \\
\text { Support }\end{array}$} & $\begin{array}{l}\text { Concept } \\
\text { Development }\end{array}$ & $\begin{array}{l}\text { This involves the teacher's ability to employ strategies to promote children's higher order } \\
\text { thinking skills (e.g., open ended questions, brainstorming, prediction \& integration of } \\
\text { information) instead of focusing on rote \& fact-based learning. }\end{array}$ \\
\hline & $\begin{array}{l}\text { Quality of } \\
\text { Feedback }\end{array}$ & $\begin{array}{l}\text { This involves the teacher's ability to provide children with 1) quality verbal evaluation } \\
\text { about their work, and 2) comments, ideas and feedback with information to support their } \\
\text { understanding of the process of learning instead of just the correctness of the end } \\
\text { product. }\end{array}$ \\
\hline & $\begin{array}{l}\text { Language } \\
\text { Modelling }\end{array}$ & $\begin{array}{l}\text { This involves the teacher's ability to use quality language-stimulation and language- } \\
\text { facilitation techniques during individual, small-group, and large-group interactions with } \\
\text { children (e.g., self \& parallel talk, open-ended questions, repetition, expansion/extension } \\
\& \text { use of advanced language). }\end{array}$ \\
\hline
\end{tabular}

\section{Procedure}

In this study, a team of two researchers trained in CLASS visited the participating pre-schools to observe and video-record the teacher-child interactions in the K classrooms. Each classroom was observed and video-recorded for 3 to 4 hours (depending on the duration of their program). As the purpose of the study was to capture instances of teacher-child interactions on a typical day in the participating pre-school, the teachers were not given any instructions or directions regarding the content or pedagogy for the activities to be observed and video-recorded. Although the Nurturing Early Learners (NEL) Framework (Ministry of Education [MOE], 2012) was launched by the Ministry of Education in 2013, it is a recommended and not a mandatory guideline to be used by pre-schools to design and develop their curriculum (Tan, 2017). Hence, the curriculum (including the content \& pedagogy for the activities) could vary among the pre-schools.

\section{Data Analysis}

A qualitative approach was adopted for the study in order to obtain rich and insightful data (Bogdan \& Biklen, 2003; Cohen, Manion \& Morrison, 2011; Creswell, 2008). A team of two researchers trained in CLASS organised, observed and rated the video-recorded classroom observations of the pre-school classroom. 
Table 2. CLASS Scoring for Quality Interactions (Pianta et al., 2008)

\begin{tabular}{lll}
\hline Score & Range & Indication of Quality Interactions \\
\hline 1,2 & Low & few \\
\hline $3,4,5$ & Mid & some \\
\hline 6,7 & High & many \\
\hline
\end{tabular}

Each of the video-recorded classroom observations was organised and divided into four to six rounds of 20-minute video segments, depicting the teacher in different classroom activities (e.g., mealtime, large group activity, small group activity, free play, etc.). Each video segment was then followed by a tenminute scoring session. During the scoring session, each dimension was rated from 1 to 7 . As summarised in Table 2, a score of 1 or 2 indicates that the classroom is in the low range when there were few or no indicators of quality teacher-child interactions; 3, 4, or 5 indicates that the classroom is in the moderate range when there were some indicators of quality teacher-interactions; and 6 or 7 indicates that the classroom is in the high range when there were many indicators of quality teacher-child interactions. An average score across the four to six segments was then calculated for each of the ten dimensions. This average score obtained for each of the ten dimensions was then analysed by making reference to the literature.

\section{Results}

The results from the study will be presented according to the three domains which are Emotional Support, Classroom Organisation and Instructional Support. Figure 2 provides a summary of the results which is, most pre-schools scored in the moderate range (3 to 5) for Emotional Support and Classroom Organisation, but in the low range (1 to 2 ) for Instructional Support.

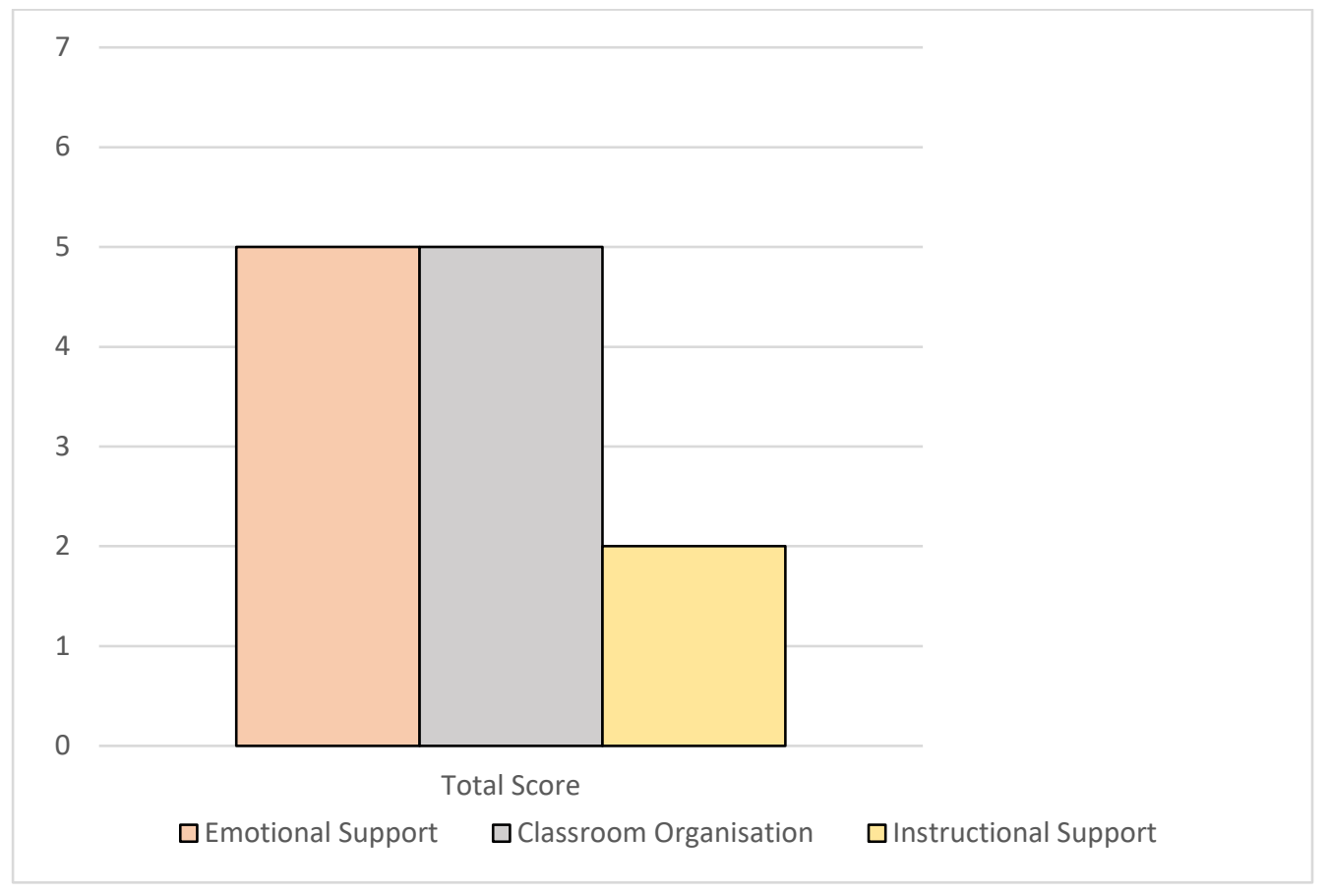

Figure 2. Quality of teacher-child interactions in Singapore pre-schools

\section{Emotional Support}

As a whole, most pre-schools scored in the moderate range (3 to 5) for this domain as they displayed some indicators of quality teacher-child interactions. As indicated in Table 1, Emotional Support comprises the following dimensions which are Positive Climate, Negative Climate, Teacher Sensitivity and Regard for Student Perspectives. Of the four dimensions that contribute towards Emotional Support, scores for Teacher Sensitivity and Regard for Student Perspectives were in the lowest range (Table 3). 
Enhancing the quality of teacher-child interactions...

Table 3. CLASS Scoring for Emotional Support

\begin{tabular}{lcc}
\hline Dimension & Range & Indication of Quality Interactions \\
\hline Positive Climate & moderate & some \\
\hline Negative Climate & moderate & some \\
\hline Teacher Sensitivity & low & few \\
\hline Regard for Student Perspectives & low & few \\
\hline
\end{tabular}

As explained in Table 1 above, Teacher Sensitivity involves the extent to which the teacher 1) provides comfort, reassurance and encouragement, 2) is aware of children's needs for support, 3) provides individualized support, 4) is responsive to children's emotions, 5) addresses problems in a timely manner, and 6) creates a classroom in which children are comfortable seeking out the teacher and volunteering responses.

The low range scores for Teacher Sensitivity indicated that few or no indicators of this dimension were observed in the pre-school classrooms (Table 3). Teachers were seldom aware of students in need of extra support, assistance or attention. The teachers were responsive to children on a few occasions but most of the time, they were more dismissive or unresponsive; and they responded to the interests, needs and abilities of a few children but not the others. The teachers were also seldom effective in addressing children's problems and concerns; and children rarely sought support from, shared ideas with, or responded to questions from the teachers.

As explained in Table 1, Regard for Student Perspectives involves the extent to which the teacher 1) provides classroom activities which are rigidly structured or regimented, 2) shows flexibility with respect to children's ideas, 3) follows children's leads, supports autonomy and leadership, and 3) maintains a balance of teacher talk and child talk in the classroom.

The low range scores for Regard for Student Perspectives indicated that few or no indicators of this dimension were observed in the pre-school classrooms (Table 3). Teachers rarely followed the children's lead, and were controlling most of the time. They seldom provided support for children's autonomy and leadership, and opportunities for child-talk and expression. On most occasions, there was teacher-talk, and teachers seemed to be somewhat controlling of children's movement and placement during the activities.

\section{Classroom Organisation}

As a whole, most pre-schools scored in the moderate range (3 to 5) for this domain as they displayed some indicators of quality teacher-child interactions. As indicated in Table 1, Classroom Organisation comprises the following dimensions which are Behaviour Management, Productivity, and Instructional Learning Formats. Of the three dimensions that contributed towards Classroom Organisation, scores for Instructional Learning Formats were in the lowest range (Table 4).

Table 4. CLASS Scoring for Classroom Organisation

\begin{tabular}{lcc}
\hline Dimension & Range & Indication of Quality Interactions \\
\hline Behaviour Management & moderate & some \\
\hline Productivity & moderate & some \\
\hline Instructional Learning Formats & low & few \\
\hline
\end{tabular}

As explained in Table 1, Instructional Learning Formats involves the teacher's ability to use 1) available activities, method of presentation, groupings, and range of materials to maximize children's engagement and exploration in learning, 2) questions to engage children and 3) activities to expand children's learning.

The low range scores for the Instructional Learning Formats indicated that few or no indicators of this dimension were observed in the pre-school classrooms (Table 4). Teachers merely provided activities 
for the children, and rarely facilitated activities to encourage their engagement and involvement. Teachers were inconsistent in their use of a variety of modalities and materials to gain children's attention and participation during activities. Hence, children did not seem to be engaged, interested or involved in the activities most of the time.

\section{Instructional Support}

As a whole, most pre-schools scored in the low range (1 to 2 ) for this domain as they displayed very few or no indicators of quality teacher-child interactions. As indicated in Table 1, Instructional Support comprises the following dimensions which are Concept Development, Quality of Feedback, and Language Modelling. Unlike Emotional Support and Classroom Organisation, the score for the three dimensions that contributed to Instructional Support were all in the low range (Table 5).

Table 5. CLASS Scoring for Instructional Support (Pianta et al., 2008)

\begin{tabular}{lcc}
\hline Dimension & Range & Indication of Quality Interactions \\
\hline Concept Development & low & few \\
\hline Quality of Feedback & low & few \\
\hline Language Modelling & low & few \\
\hline
\end{tabular}

As explained in Table 1, Concept Development involves the teacher's ability to employ strategies to promote children's higher-order thinking skills (e.g., open-ended questions, brainstorming, prediction \& integration of information) instead of focusing on rote \& fact-based learning.

Low scores for Concept Development indicated that very few or no indicators of this dimension were observed in the pre-school classrooms (Table 5). Teachers rarely used discussions and activities to encourage analysis and reasoning, or provided opportunities for children to be creative and/or generate their own ideas and products. On most occasions, concepts and activities were presented independent of one another, and children were not asked to apply their previous learning. Teachers also seldom related concepts to the children's actual lives.

As explained in Table 1, Quality of Feedback involves the teacher's ability to provide children with 1) quality verbal evaluation about their work, and 2) comments, ideas and feedback with information to support their understanding of the process of learning instead of just the correctness of the end product.

The low scores for Quality of Feedback indicated that very few or no indicators of this dimension were observed in the pre-school classrooms (Table 5). Teachers seldom supported children's learning, dismissed their responses or actions as incorrect, and ignored their problems in understanding. On most occasions, teachers gave only cursory feedback to children, and rarely queried, probed or prompted them to explain their thinking or actions. Teachers also rarely provided additional information to expand on the children's understanding or actions, or offered encouragement of children's efforts that increased their involvement and persistence.

As explained in Table 1, Language Modelling involves the teacher's ability to use quality languagestimulation and language-facilitation techniques during individual, small-group, and large-group interactions with children (e.g., self \& parallel talk, open-ended questions, repetition, expansion/extension $\&$ use of advanced language).

The low scores for Language Modelling indicated that very few or no indicators of this dimension were observed in the pre-school classrooms (Table 5). The majority of teacher's questions were closedended, and the teachers seldom repeated or extended the children's responses. Teachers rarely mapped their own actions and the children's actions through language and description, and they did not use advanced language with children. This is also very much linked to the limited presence or absence of meaningful conversations in the classroom. 
Enhancing the quality of teacher-child interactions...

\section{Discussion and Conclusion}

The results for the three domains (Emotional Support, Classroom Organisation \& Instructional Support) will be consolidated and discussed. Possible reasons and explanations will be provided as well as suggestions to improve or enhance the quality of teacher-child interactions in Singapore pre-schools will be proposed by making reference to the literature.

As a whole, most pre-schools scored in the moderate range (3 to 5) for the domains on Emotional Support and Class Organisation as only some indicators of quality teacher-child interactions were displayed during the classroom observations. There are possible reasons for this result. Firstly, the class size was large and the teacher-to-child ratio was rather high. There could be a maximum of 20 children in the $\mathrm{K} 1$ classroom and 25 children in the K2 classroom, and there was usually one teacher and sometimes, one assistant teacher who usually taught the mother tongue language. Secondly, teachers needed to complete a tight and sometimes, inflexible schedule of activities within the 3- or 4- hour kindergarten programme. This left the teacher with very little time to pay attention and respond to each and every child during the tight programme in the classroom. Activities were usually very much teacher-directed and as a result, there was very little child-talk or conversations as well as facilitation, support or scaffoldin for individual children's learning.

However, teachers could provide more positive support if they were skilful in breaking up the large group into smaller groups, and conducting free play and guided activities simultaneously in the various learning centres in the classroom ( $\mathrm{Ng} \&$ Bull, 2018). This requires the teachers to possess the necessary knowledge, skills and experience to organise and manage a large class size. Hence, teacher-training institutes could take this into consideration in their teacher education, professional development and coaching programmes (Karuppiah, 2015; Ng \& Bull, 2018; Pianta, et al., 2014; Schachter et al., 2019; Zan \& Donegan-Ritter, 2014).

There could also be other reasons such as child factors (e.g., characteristics, temperament, selfregulation, attention \& socio-emotional skills) (Ladd et al., 1999; Pianta \& Stuhlman, 2004). For example, some children could require more attention, and the teacher had to spend more time with these children. This could potentially pose a challenge to maintaining quality teacher-child interactions, if the class size was large and the teacher-to-child ratio was high in that classroom (Hoang et al., 2018; NICHD ECCRN, 2004; OECD, 2018). Hence, in view of these challenging conditions, the government could review the class size and teacher-to-child ratio in the pre-schools.

Given the current shortage of good teachers (due to challenges in attracting \& retaining them) in the Singapore pre-school sector, this may not be a feasible option. Hence, reviewing the curriculum in the preschool to free up time for quality teacher-child interactions in the pre-school classroom could be another option (Bautisa, Ng, Munez, \& Bull, 2016; OECD, 2018; Tan, 2017). However, parents in Singapore are particular about their children maximising their learning time especially, in the academic areas (literacy \& numeracy) while they are in the pre-school (Bach \& Christensen, 2017; Lim-Ratnam, 2013). Hence, besides governmental support, parental support and education would also be required for this option to work.

As a whole, most pre-schools scored in the low range (1 to 2) for the domain on Instructional Support as only a few indicators of quality teacher-child interactions were displayed during the classroom observations. Interestingly, the low score for this domain is consistent with findings from other countries including China and the U.S. (Slot, 2017). There could be possible reasons for this result which are also similar to the ones provided previously on Emotional Support and Classroom Organisation. These reasons make it challenging for teachers to provide quality instructional support for children in the pre-school classroom. Again, besides reviewing teacher education and professional development programmes (Karuppiah, 2015; Ng \& Bull, 2018; Pianta et al., 2014; Schachter et al., 2019; Zan \& Donegan-Ritter, 2014), the class size, teacher-to-child ratios and curriculum in the pre-school could also be reviewed (Hoang et al., 2018; NICHD ECCRN, 2004; OECD, 2018; Tan, 2017;).

Additionally, it is also important to consider the design, delivery and focus of training carefully 
(Pianta et al., 2014) as well as provide opportunities for self-reflection (Schachter et al., 2019) and sustained training experiences (Zan \& Donegan-Ritter, 2014) in order to ensure the effectiveness of professional development for teachers. Since the score was lowest for this domain, it may also be important to consider providing coaching and useful resources (e.g., local videos of good practices) to help teachers understand, appreciate and acquire the necessary skills to promote quality instructional support in the pre-school classrooms (Langeloo, Mascareno, Deunk, Klitzing, \& Strijbos, 2019; Schachter et al., 2019; Zan \& DoneganRitter, 2014). Other factors such as higher salaries, a positive organisational climate and professional learning communities have also been found to improve teachers' self-image and well-being as well as teachers' motivation and teacher-child interactions in the pre-school classrooms (OECD, 2018).

In summary, it appears that the quality of interactions was generally moderate for Emotional Support and Classroom Organisation but somewhat low for Instructional Support. Hence, the overall quality of teacher-child interactions in Singapore pre-schools could be described to be in the low to moderate range. Possible reasons and explanations were presented, and suggestions to improve or enhance the quality of teacher-child interactions were proposed. These suggestions include reviewing teacher education, professional development and coaching programmes, developing local video resources, setting up professional learning communities, reviewing government policies and regulations, and improving teachers' self-image, well-being and working conditions in the pre-schools.

\section{Limitations}

Although this exploratory study was a good start and would make a contribution to the pre-school sector in Singapore, there are some key limitations which are as follows. The sample comprised mainly kindergartens. Childcare centres which have a longer programme could potentially provide more time for the teachers to provide quality interactions with the children. However, this depends on the class size and teacher-to-child ratio as well as whether the teachers possess the necessary knowledge, skills and experience to support quality teacher-child interactions in the classroom.

There could be researcher-bias in the analysis and interpretation of the data. However, all measures have been taken to ensure that researcher-bias was kept to a minimum by maintaining interrater reliability, and constantly referring to the literature and purpose of the study.

\section{Implications and Future Research}

The information gathered from the study could contribute to the database on research in the care and education of young children in Singapore. It could also be used to inform various stakeholders in the pre-school sector, on the importance of teacher-child interactions. Teachers and leaders could engage in critical self- evaluation and reflection to enhance/improve their classroom pedagogies and practices. A new study comprising both kindergartens and childcare centres could also be carried out to ascertain if the duration of the pre-school programme would make a significant difference in the quality of teacher-child interactions in the classroom.

Findings from this study could also contribute to the growing research on teacher education and professional development for pre- and in- service teachers in Singapore. More local resources (such as exemplary classroom videos of good practice) could also be developed to support teacher education and professional development programmes for teachers (Hamre et al., 2012; Langeloo et al., 2019; Schachter et al., 2019).

While teacher-training institutes could consider reviewing their pre-school teacher-education and professional development programmes, the government could consider reviewing their policies, regulations and the working conditions in the pre-sector. More research could also be done in identifying what teachers think are the factors which affect their interactions with children; and how they can improve the quality of interactions with children in the classroom. Such valuable information from the teachers themselves could be used to inform policy, teacher education and professional development in very meaningful ways. 
Enhancing the quality of teacher-child interactions...

\section{Declarations}

Acknowledgements: The Author would like to thank the researchers and participants in the study.

Competing interests: The Author declares that there was no conflict of interest. The views expressed in this article do not necessarily reflect those of the university.

Funding: This study was supported and funded by the Office of Educational Research, National Institute of Education, Nanyang Technological University, Singapore (Grant OER 09/14 RB).

\section{References}

Bach, D., \& Christensen, S. (2017). Battling the tiger mother: Pre-School reform and conflicting norms of parenthood in Singapore. Children \& Society, 31(2), 134-143. https://doi.org/10.1111/chso.12162

Bautisa, A., Ng, S. C., Múñez, D. \& Bull, R. (2016). Learning areas for holistic education: kindergarten teachers' curriculum priorities, professional development needs, and beliefs. International Journal of Child Care and Education Policy. https://doi.org/10.1186/s40723-016-0024-4

Berthelsen, D., Brownlee, J., \& Karuppiah, N. (2011). Teachers' beliefs and practices in early childhood education in Singapore. Singapore: Pearson Education.

Bertram, T., Pascal, C., Cummings, A., Delaney, S., Ludlow, C., Lyndon, H., \& Stancel-Piatak, A. (2016). Early childhood policies and systems in eight countries: Findings from IEA's early childhood education study. International Association for the Evaluation of Educational Achievement. https://doi.org/10.1007/978-3-319-39847-1

Bogdan, R. C., \& Biklen, S. K. (2003). Qualitative research for education: An introduction to theories and methods. Boston, MA: Pearson Education.

Burchinal, M. R., Peisner-Feinberg, E., Pianta, R. C., \& Howes, C. (2002). Development of academic skills from preschool through second grade: Family and classroom predictors of developmental trajectories. Journal of School Psychology, 40(5), 415-436. https://doi.org/10.1016/S0022-4405(02)00107-3

Cohen, L., Manion, L., \& Morrison, K. (2011). Research methods in education. London: Routledge Falmer.

Creswell, J. W. (2008). Educational research, planning, conducting and evaluating quantitative and qualitative research (3rd Ed.). New Jersey: Pearson Education.

Early Childhood Development Agency [ECDA]. (2020). Teacher Certification. 15 February 2021 retrieved from https://www.ecda.gov.sg/Educators/Pages/Teacher-Certification.aspx

Fukkink, R., Helmerhorst, K., Deynoot Schaub, M. G., \& Sluiter, R. (2019). Training interaction skills of pre-service ECEC teachers: Moving from in-service to pre-service professional development. Early Childhood Education Journal, 47, $497-507$. https://doi.org/10.1007/s10643-019-00928-6

Hamre, B. K., Pianta, R. C. Burchinal, M., Field, S., LoCasale-Crouch, Downer, J. T., ... Scott-Little, C. (2012). A course on effective teacher-child interactions: Effects on teacher beliefs, knowledge, and observed practice. American Educational Research Journal, 49(1), 88-123. https://doi.org/10.3102/0002831211434596

Hoang, N., Holopainen, L., \& Siekkinen, M. (2018). Quality of teacher-child interactions and its relations to children's classroom engagement and disaffection in Vietnamese kindergartens. International Journal of Early Years Education, 26(4), 387-402. https://doi.org/10.1080/09669760.2018.1478281

Karuppiah, N. (2015). Childcare staff's and parents' beliefs about quality care for infants/toddlers in centre-based programmes in Singapore. Australian Journal of Early Childhood, 30(4), 105-113. https://doi.org/10.1177/183693911504000314

Ladd, G. W., Birch, B. H., \& Buhs, E. S. (1999). Children's social and scholastic lives in kindergarten: Related spheres of influence? Child Development, 70(6), 1373-1400. https://doi.org/10.1111/1467-8624.00101

Langeloo, A., Mascareno, M. L, Deunk, M. I., Klitzing, N. F., \& Strijbos, J. W. (2019). A systematic review of teacher-child interactions with multilingual young children. Review of Educational Research, 89(4), 536-568. https://doi.org/10.3102/0034654319855619

Lim-Ratnam, C. (2013). Tensions in defining quality pre-school education: The Singapore context. Educational review, 65(4), 416-431. https://doi.org/10.1080/00131911.2012.707641

Mashburn, A. J., Pianta, R. C., Hamre, B. K., Downer, J. T., Barbarin, O. A., Bryant, D., ... Howes, C. (2008). Measures of classroom quality in prekindergarten and children's development of academic, language, and social skills. Child Development, 79(3), 732749. https://doi.org/10.1111/j.1467-8624.2008.01154.x

Ministry of Education [MOE]. (2012). Nurturing Early Learners: A Curriculum for Kindergartens in Singapore. 10 August 2021 retrieved from https://www.nel.moe.edu.sg/qq1/slot/u143/Resources/Downloadable/pdf/kindergarten-curriculum-framework.pdf

National Institute of Child Health and Human Development, Early Child Care Research Network [NICHD ECCRN]. (2004). Does class size in first grade relate to children's academic and social performance or observed classroom processes?. Developmental 
Psychology, 40(5), 651-664. https://doi.org/10.1037/0012-1649.40.5.651

Ng, S. C., \& Bull, R. (2018). Facilitating social emotional learning in kindergarten classrooms: Situational factors and teachers' strategies. International Journal of Early Childhood, 50, 335-352. https://doi.org/10.1007/s13158-018-0225-9

Organisation for Economic Co-operation and Development [OECD].(2018). Engaging young children: Lessons from research about quality in early childhood education and care. 15 February 2021 retrieved from http://www.oecd.org/education/engaging-youngchildren-9789264085145-en.htm

Pianta, R. C., \& Stuhlman, M. W. (2004). Teacher-child relationships and children's success in the first years of school. School Psychology Review, 33(3), 444-458. https://doi.org/10.1080/02796015.2004.12086261

Pianta, R. C., DeCoster, J., Cabell, S., Burchinal, M., Hamre, B. K. , Downer, J., ... Howes, C. (2014). Dose-response relations between preschool teachers' exposure to components of professional development and increases in quality of their interactions with children. Early Childhood Research Quarterly, 29(4), 499-508. https://doi.org/10.1016/j.ecresq.2014.06.001

Pianta, R. C., LaParo, K., \& Hamre, B. K. (2008). Classroom Assessment Scoring System (CLASS) manual. Baltimore, MD: Brookes Publishing.

Ramey, C. T., \& Ramey, S. L. (2004). Early learning and school readiness: Can early intervention make a difference? Merrill Palmer Quarterly, 50(4), 471-491. https://doi.org/10.1353/mpq.2004.0034

Schachter, R. E., Gerde, H. K., \& Hatton-Bowers, H. (2019). Guidelines for Selecting Professional Development for Early Childhood Teachers. Early Childhood Education Journal, 47(4), 395-408. https://doi.org/10.1007/s10643-019-00942-8

Slot, P. (2017). Literature review on early childhood education and care quality: Relations between structural characteristics at different levels and process quality, Internal document. OECD, Paris. 15 February 2021 retrieved from https://www.oecdilibrary.org/docserver/9789264085145-6en.pdf?expires=1613379403\&id=id\&accname=guest\&checksum=A5BB59ECE56C794FE9DEF6605F6A729F

Tan, C. T. (2017). Enhancing the quality of kindergarten education in Singapore: Policies and strategies in the 21st century. International Journal of Child Care and Education Policy, 11, 7. https://doi.org/10.1186/s40723-017-0033-y

Thomason, A. C., \& LaParo, K. (2009). Measuring the quality of teacher-child interactions in toddler child care. Early Education and Development, 20(2), 285-304. https://doi.org/10.1080/10409280902773351

Zan, B., \& Donegan-Ritter, M. (2014). Reflecting, coaching and mentoring to enhance teacher-child interactions in Head Start Classrooms. Early Childhood Education Journal, 42(2), 93-104. https://doi.org/10.1007/s10643-013-0592-7 